\title{
PENENTUAN KADAR PROTEIN DAN KARBOHIDRAT PADA LIMBAH BATANG POHON PISANG KEPOK (MUSA PARADISIACA NORMALIS)
}

\author{
Determination of Protein and Carbohydrate Levels in Waste of \\ Banana Kepok (Musa paradisiaca Normalis)
}

\author{
*Noviasri Dhamayanti, Vanny M. A. Tiwow, dan Siti Nuryanti \\ Pendidikan Kimia/FKIP - Universitas Tadulako, Palu - Indonesia 94118 \\ Received 15 September 2018, Revised 14 October 2018, Accepted 24 November 2018
}

\begin{abstract}
The aim of this study was to determine protein and carbohydrate levels contained in waste of banana kepok (Musa paradisiaca Normalis) trees. Samples were taken from Mpanau Sigi Central Sulawesi. This study used Kjeldahl method in determining protein level, and antrone method in determining reducing sugar level. The analysis results obtained in the hard layer of banana tree are 3.05\% of protein level and $6.75 \%$ of carbohydrate level, while in the soft layer of banana tree are $0.08 \%$ of protein level and $4.75 \%$ of carbohydrate level, respectively. This study concluded that protein and carbohydrate levels obtained from the hard layer of banana kepok trees waste is higher, than literatures.
\end{abstract}

Keywords: waste of banana kepok tree, protein, carbohydrates.

\section{Pendahuluan}

Pisang (musa paradisiaca) berasal dari Asia Tenggara dan telah menyebar keseluruh dunia, termasuk Indonesia. Buah pisang sangat popular dan digemari oleh semua lapisan masyarakat. Pisang merupakan tanaman buah-buahan yang tumbuh dan tersebar di seluruh Indonesia. Indonesia merupakan negara penghasil pisang terbesar di Asia. Pisang dikategorikan menjadi 3 golongan yaitu pisang yang dapat dikonsumsi, pisang yang diambil pelepah batangnya sebagai serat dan pisang yang dipergunakan sebagai tanaman hias (Sriharti \& Salim, 2008).

Produksi pisang Indonesia cukup besar. Berdasarkan Angka Tetap (ATAP) tahun 2013 produksi pisang mencapai 6,28 juta ton. Untuk wilayah Asia, Indonesia termasuk penghasil pisang terbesar karena 50\% produksi pisang Asia dihasilkan oleh Indonesia. Hampir seluruh wilayah Indonesia merupakan daerah penghasil pisang karena didukung oleh iklim yang sesuai. Pengembangan pisang dipengaruhi oleh beberapa faktor, antara lain iklim, media tanam dan ketinggian tempat. Namun demikian $90 \%$ produksi pisang masih digunakan untuk konsumsi dalam negeri, sedangkan untuk ekspor hanya 10\% (Suhartono, 2008).

Pisang merupakan salah satu komoditas nasional yang memiliki kandungan gizi yang lengkap. Pisang memiliki kandungan gizi yang cukup tinggi dan lengkap. Kandungan gizi pisang terdiri dari air, karbohidrat, protein, lemak, dan vitamin A, B1, B2 dan C (Taufik, dkk., 2011).

Menurut (Munadjim (1988), manfaat pisang yang paling banyak diketahui penduduk hanya sebatas buahnya saja, sehingga setelah diambil buahnya, tanaman pisang (Batang pisang) tidak mempunyai nilai

\section{*Correspondence:}

\section{Noviasri Dhamayanti}

Program Studi Pendidikan Kimia, Fakultas Keguruan dan IImu Pendidikan, Universitas Tadulako

e-mail: noviasridhamayanti@yahoo.co.id

Published by Universitas Tadulako 2018 yang berharga lagi, hanya akan membusuk. Batang pisang belum banyak digunakan untuk kompos padahal dalam batang pisang terdapat unsur-unsur penting yang dibutuhkan tanaman seperti nitrogen $(\mathrm{N})$, posforus (P) dan kalium (K) (Wulandari, dkk.,2011).

Sulawesi Tengah merupakan daerah penghasil tanaman pisang meskipun bukan menjadi komoditas unggulan daerah. Menurut data SDA Provinsi Sulawesi Tengah tahun 2007, jumlah produksi tanaman pisang mencapai 2.887 ton/ha. Melihat data tersebut maka begitu banyak limbah batang pohon pisang yang dihasilkan.

Djaja (2008) mengatakan limbah merupakan bahan yang terbuang atau dibuang dari suatu aktivitas manusia atau proses alam yang tidak atau belum mempunyai nilai ekonomi dan berdampak negatif pada lingkungan. Batang pisang merupakan limbah dari tanaman pisang yang telah ditebang untuk diambil buahnya dan merupakan limbah pertanian potensil yang belum banyak pemanfaatannya. Beberapa penelitian telah mencoba untuk memanfaatkannya antara lain untuk papan serat (Rahman, 2006).

Tanaman pisang telah lama dikenal oleh masyarakat Indonesia, buahnya dapat dimakan langsung atau diolah terlebih dahulu. Selain buah, kulit pisang juga memiliki banyak manfaat, antara lain antioksidan. Penelitian yang dilakukan oleh Someya dkk., (2002) mengatakan bahwa pada kulit pisang mengandung aktivitas antioksidan yang cukup tinggi dibandingkan dengan dagingnya. Aktivitas antioksidan pada kulit pisang mencapai $94,25 \%$ pada konsentrasi $125 \mathrm{mg} / \mathrm{mL}$ sedangkan pada buahnya hanya sekitar $70 \%$ pada konsentrasi $50 \mathrm{mg} / \mathrm{mL}$ (Fatemeh dkk., 2012).

Bunga pisang, (dikenal sebagai jantung pisang) dapat digunakan untuk sayur, manisan, acar, maupun lalapan. Daunnya lazim digunakan untuk pembungkus 
makanan, yang dapat memberikan rasa harum khas pada nasi yang dibungkus dalam keadaan panas. Namun, di sisi lain belum banyak yang memanfaatkan batang pisang sehingga menumpuk menjadi limbah. Batang pisang merupakan bahan organik yang berpotensi sebagai bahan baku kompos. Hasil penelitian Pratama dkk. (2011) ekstrak kulit pisang mengandung flavones, flavonol, flavanone dan polimethoxyflavone yang berpotensi sebagai phytoestrogen.

Beberapa daerah seperti Bali, batang pisang digunakan sebagai sumber makanan atau sayuran segar. Sayuran yang terbuat dari batang pisang ini disebut "ares". Batang pisang yang digunakan adalah batang pisang yang masih muda, kira-kira berumur 1 bulan. Sayur ares ini umumnya dihidangkan sebagai hidangan selamatan dalam peristiwa-peristiwa adat. Selain dapat dijadikan sebagai sumber makanan untuk manusia, biasanya peternak kuda, sapi, babi dan lain-lain mengunakan batang pisang sebagai makanan tambahan dimusim kering. Batang pisang yang digunakan adalah batang pisang yang masih segar, yaitu yang baru dipetik buahnya dan tidak rusak atau busuk (Munadjim, 1988). Selain limbah batang pisang, limbah kulit pisang juga dapat dijadikan pakan ternak terutama jenis ayam pedaging (Hidayat dkk., 2016). Hasil penelitian Djoht (2002) pada suku Karon di Papua, pisang merupakan makanan pokok yang mereka sebut Weu.

Limbah batang pisang juga dapat dimanfaatkan untuk tali bibit tanaman padi. Kandungan nilai gizi dari batang pisang adalah bahan kering 8,62\%; abu 24,31\%; protein kasar 4,81\%; serat kasar 27,73\%; selulosa 26,64\%; dan lignin 9,92\% (Hasrida, 2011). Batang pohon pisang cukup banyak mengandung zatzat mineral (Suprihatin, 2011). Menurut Wina (2001) kandungan lemak kasar batang pisang berkisar antara $3,20 \%$ sampai $8,10 \%$.

Artikel ini bertujuan untuk mengurai kadar protein dan karbohidrat yang terdapat pada limbah batang pohon pisang kepok (musa paradisiacal normalis).

\section{Metode}

Alat yang digunakan yaitu: labu Kjeldahl, gelas kimia, timbangan analitik, pipet tetes, gelas ukur, labu ukur, erlenmeyer, corong, pengaduk, botol semprot, kertas saring, spektrofotometer UV-Vis (Genesys 10 UV), spectrodirect (Spectroll II), penjepit, aluminium foil dan oven. Bahan yang digunakan adalah: Tablet kjeldahl, asam sulfat pekat $\left(\mathrm{H}_{2} \mathrm{SO}_{4}\right)$, aquades, asam clorida pekat $(\mathrm{HCl})$, anthrone.

\section{Penyiapan sampel}

Batang pohon pisang kepok (musa paradisiaca normalis) diperoleh dari daerah Mpanau, Kecamatan
Bagian luar batang pohon pisang dikupas kemudian bagian dalam dari batang pohon pisang tersebut. diambil 100 gram dipotong menjadi bagian kecil-kecil, kemudian dikeringkan menggunakan oven pada suhu $60{ }^{\circ} \mathrm{C}$ selama 6 jam.

\section{Penentuan kadar protein}

1 gram sampel dimasukkan ke labu Kjeldahl dan ditambahkan 1 butir tablet Kjeldahl. $10 \mathrm{~mL}$ ditambahkan larutan asam sulfat pekat. Didestruksi (dipanaskan) semua bahan dalam labu Kjeldahl dan cairan menjadi jernih. Diencerkan dengan $25 \mathrm{~mL}$ aquades dan didinginkan sampai suhu kamar. Kemudian filtrat diambil $10 \mathrm{~mL}$ untuk ditentukan kadar nitrogen total dengan menggunakan spectrodirect pada panjang gelombang $410 \mathrm{~nm}$. Melakukan perlakuan sebanyak dua kali (duplo). Kemudian menghitung kadar protein dengan rumus (Aprianto dkk., 1988):

$\%$ Protein $=\frac{\mathrm{N} x \text { faktor pengenceran } \times 6,25 \times \text { Jumlah } \mathrm{mL} \text { sampel }}{\text { berat sampel }} \times 100 \%$

\section{Pembuatan larutan standar glukosa}

Larutan glukosa standar dibuat dengan konsentrasi masing-masing $0,10,20,30,40,50 \mathrm{ppm}$. 0,1 gram serbuk glukosa dimasukkan dalam labu ukur $100 \mathrm{~mL}$, diencerkan menggunakan aquades sampai tanda batas. $10 \mathrm{~mL}$ larutan stok glukosa dimasukkan kedalam labu ukur $100 \mathrm{~mL}$ dan diencerkan sampai tanda batas. Absorbannya diukur dengan spektrofotometer UV-Vis pada panjang gelombang 490 $\mathrm{nm}$, kemudian membuat persamaan linearnya sebagai kurva standar (Bintang, 2010).

\section{Penentuan kadar karbohidrat}

1 gram sampel batang pohon pisang kepok (musa paradisiaca normalis) dilarutkan dalam $\mathrm{HCl}$ pekat 5 $\mathrm{mL}$. Disaring pada labu takar $10 \mathrm{~mL}$. Filtrat diencerkan dengan aquades sampai tanda batas. Diambil $1 \mathrm{~mL}$, kemudian ditambahkan pereaksi antrone $5 \mathrm{~mL}$. Dipanaskan selama 12 menit, didinginkan sampai suhu kamar. Setelah itu diukur serapannya dengan spektrofotometer UV-Vis pada panjang gelombang 490 $\mathrm{nm}$, dengan perlakuan sebanyak dua kali (duplo). Kadar karbohidrat dihitung dengan rumus (Faozan, 2013):

$\%$ karbohidrat $=\frac{\text { berat glukosa ppm } \times 0,91 \times \text { volume sampel }}{\text { berat sampel }} \times 100 \%$

\section{Hasil dan Pembahasan}

Pada penelitian ini menentukan kadar protein dan karbohidrat pada limbah batang pohon pisang kapok 
(musa paradisiaca normalis) dengan menggunakan metode kjehldal dan antrone. Batang pohon pisang kapok (musa paradisiaca normalis) yang digunakan diambil dari Desa Mpanau, Kecamatan Biromaru Kabupaten Sigi. Penentuan Kurva Kalibrasi Standar Glukosa

Hasil pengukuran serapan larutan standar glukosa dapat dilihat pada Tabel 1.

Tabel 1. Data serapan larutan standar glukosa

\begin{tabular}{cc}
\hline Standar glukosa $(\mathrm{ppm})$ & Absorban \\
\hline 0 & 0 \\
10 & 0,076 \\
20 & 0,18 \\
30 & 0,25 \\
40 & 0,32 \\
50 & 0,42 \\
\hline
\end{tabular}

Menggunakan persamaan regresi linier hubungan antara konsentrasi glukosa dengan serapan yaitu, $\mathrm{y}=$ $0,008 \mathrm{x}$ dan $r=0,996$. Kurva kalibrasi hubungan antara glukosa dan absorban seperti pada Gambar 1.

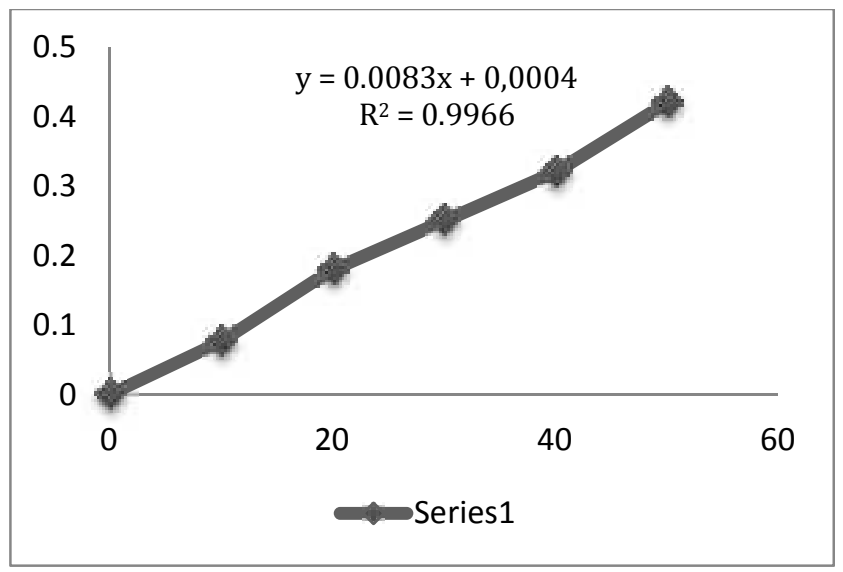

Gambar 1. Kurva kalibrasi hubungan antara glukosa (\%) dengan absorban

\section{Penentuan kadar protein dan karbohidrat}

Hasil penelitian kadar protein dan karbohidrat dari limbah batang pohon pisang kepok dapat dilihat pada Tabel 2.

Tabel 2. Kadar protein dan karbohidrat pada limbah batang pohon pisang kepok

\begin{tabular}{cccccccc}
\hline \multirow{2}{*}{$\begin{array}{c}\text { N } \\
\mathbf{0}\end{array}$} & Sampel & \multicolumn{6}{c}{ Kadar } \\
\cline { 3 - 8 } & & \multicolumn{3}{c}{ Protein (\%) } & \multicolumn{4}{c}{ Karbohidrat (\%) } \\
\hline & I & II & $\begin{array}{l}\text { Rata- } \\
\text { rata }\end{array}$ & I & II & $\begin{array}{l}\text { Rata- } \\
\text { rata }\end{array}$ \\
1. & $\begin{array}{l}\text { Lapisan } \\
\text { Keras }\end{array}$ & 2,68 & 3,43 & $\mathbf{3 , 0 5}$ & 7,6 & 5,9 & $\mathbf{6 , 7 5}$ \\
& $\begin{array}{l}\text { Lapisan } \\
\text { 2. }\end{array}$ & 0,075 & 0,084 & $\mathbf{0 , 0 8}$ & 4,7 & 4,8 & $\mathbf{4 , 7 5}$ \\
\hline
\end{tabular}

Limbah pada dasarnya adalah suatu bahan yang tidak dipergunakan lagi dari hasil aktifitas manusia, ataupun proses-proses alam yang belum mempunyai nilai ekonomi, bahkan mempunyai nilai ekonomi yang rendah. Dikatakan mempunyai nilai ekonomi yang rendah karena limbah dapat mencemari lingkungan dan penanganannya memerlukan biaya yang cukup besar.

Batang pisang merupakan salah satu limbah pertanian yang dihasilkan dari tanaman pisang yang telah dipanen yang dapat digunakan sebagai penghasil serat, bahan baku kain dan makanan ternak. Batang pohon pisang memiliki berbagai macam mineral antara lain kalium, kalsium, karbohidrat dan protein. Fungsi kalsium dalam tanaman untuk membentuk dinding sel yang sangat diperlukan dalam proses pembentukan sel baru, mendorong terbentuknya buah dan biji, sedangkan dalam tanah berfungsi untuk menetralisir pH (Nuryani \& Susanto, 2002). Pada penelitian ini difokuskan pada protein dan karbohidrat.

\section{Kadar protein}

Penentuan kadar protein pada batang pisang menggunakan metode Kjeldhal. Penentuan protein dengan metode Kjeldhal sering disebut dengan penentuan kadar protein kasar, yaitu dengan menentukan jumlah nitrogen $(\mathrm{N})$ yang dikandung suatu bahan. Metode kjeldahl digunakan untuk menganalisis kadar protein kasar dalam bahan makanan secara tidak langsung karena senyawa yang dianalisisnya adalah kadar nitrogennya. Dengan mengalikan hasil analisis yang didapatkan dengan faktor konversi 6,25 sehingga diperoleh nilai protein dalam bahan makanan. Protein atau asam-asam amino yang biasanya sangat kurang dalam bahan makanan disebut asam amino pembatas. Pada kacang-kacangan asam pembatasnya adalah metionin. Analisis kadar protein dengan metode Kjeldahl pada dasarnya menggunakan proses destruksi.

Sampel yang digunakan adalah batang pohon pisang lapisan keras dan lapisan lunak. Tabel 2 menginformasikan bahwa kadar protein pada batang pohon pisang lapisan keras diperoleh hasil rata-rata yaitu 3,05\%. Hasil penelitian menunjukan bahwa kadar protein pada lapisan keras batang pohon pisang cukup tinggi dibandingkan dengan penelitian Munadjim (1988) mengatakan batang pisang memiliki kandungan protein sebesar 0,3 setiap 100 gram. Kadar protein pada batang pohon pisang lapisan lunak diperoleh hasil rata-rata $0,08 \%$, hasil penelitian ini sangat rendah jika dibandingkan dengan penelitian Munadjim (1988). Protein merupakan molekul makro yang mempunyai berat molekul antara 5000 hingga beberapa juta. Protein merupakan bagian dari semua sel hidup dan merupakan bagian terbesar setelah air (Ermawati dkk., 2016). Protein terdiri atas rantairantai panjang asam amino, yang terikat satu sama lain 
dalam ikatan peptida. Unsur nitrogen adalah unsur utama protein. Karena terdapat didalam semua protein, yang memiliki proporsi $16 \%$ dari total protein (Almatsier, 2009).

Protein merupakan molekul yang mudah terurai terhadap pemanasan. Protein mudah mengalami perubahan bentuk fisis, banyak agensia yang dapat menyebabkan perubahan sifat alamiah protein misalnya panas, asam, basa, logam, organik, solven, radiasi sinar radioaktif. Proses pemanasan membuat protein mengalami denaturasi. Denaturasi dapat mengubah sifat protein menjadi sukar larut dalam air. Denaturasi protein terjadi bila susunan ruang atau rantai polipeptida suatu molekul protein berubah. Denaturasi dapat diartikan sebagai suatu perubahan atau modifikasi terhadap struktur sekunder, tersier dan kuartener terhadap molekul protein. Denaturasi protein akan membuat protein rusak. Sehingga dengan semakin banyak protein yang terdenaturasi menyebabkan terjadinya penurunan kadar protein pada saat dianalisis dengan proses pemanasan.

\section{Kadar karbohidrat}

Karbohidrat merupakan senyawa hasil fiksasi $\mathrm{CO}_{2}$ oleh tanaman dan tersimpan dalam berbagai bentuk yaitu monosakarida, disakarida dan polisakarida (Septiani dkk., 2004). Karbohidrat merupakan komponen bahan pangan yang berperan sebagai penyuplai energi. Selain menghasilkan energi, karbohidrat dalam bahan pangan juga berperan menentukan karakteristik tekstur. kandungan serat kasar batang pisang produk fermentasi anaerob dari campuran batang pisang, lebih rendah di bandingkan dengan kandungan protein kasar batang pisang segar, hal ini diduga karena ada sebagian fraksi serat dari batang pisang mengalami degradasi menjadi komponen karbohidrat yang lebih sederhana akibat adanya pertumbuhan mikroba pembentuk asam laktat (Dhalika dkk., 2011). Menurut Rahayu \& Astuti (2015), bahan pangan yang mengandung karbohidrat tinggi salah satunya adalah pisang. Penentuan kadar karbohidrat pada batang pohon pisang menggunakan metode antrone. Metode antrone adalah salah satu metode yang digunakan untuk menentukan kadar gula pereduksi dengan menggunakan pereaksi antrone. Dari Tabel 2 kandungan karbohidrat dari batang pohon pisang lapisan keras diperoleh hasil rata-rata sebesar $6,75 \%$ dan pada lapisan lunak batang pohon pisang diperoleh hasil rata-rata $4,75 \%$.

Tabel 3. Perbandingan kadar protein dan karbohidrat rata-rata yang diperoleh dengan literatur yang ada

\begin{tabular}{llll}
\hline \multirow{2}{*}{ Kadar } & Literatur & \multicolumn{2}{c}{ Hasil } \\
\cline { 2 - 4 } & & $\begin{array}{l}\text { Lapisan } \\
\text { Keras }\end{array}$ & $\begin{array}{l}\text { Lapisan } \\
\text { Lunak }\end{array}$ \\
\hline Protein & $0,3 \%$ & $3,05 \%$ & $0,08 \%$ \\
Karbohidrat & $3,3 \%$ & $6,75 \%$ & $4,75 \%$
\end{tabular}

Hasil penelitian menunjukan bahwa kadar karbohidrat batang pohon pisang lapisan keras maupun batang pohon pisang lapisan lunak cukup tinggi dibandingkan dengan penelitian Munadjim (1988) mengatakan bahwa batang pisang memiliki kandungan karbohidrat sebesar 3,3\% setiap 100 gram.

Kadar protein dan karbohidrat yang terdapat pada batang pohon pisang lapisan keras yaitu 3,055\% dan $6,75 \%$. Hasil yang diperoleh ini, lebih tinggi dibandingkan dengan literatur yang ada yaitu 0,3\% dan 3,3\%. Hal ini dikarenakan perbedaan tempat tumbuh tanaman pisang berpengaruh terhadap kadar protein dan karbohidrat dalam batang piang. Untuk hasil yang diperoleh pada lapisan lunak batang pohon pisang, belum memiliki pembanding. Penelitian yang dilakukan oleh Munadjim (1988) hanya meneliti tentang kadar protein dan karbohidrat pada batang pohon pisang, sehingga untuk kadar protein dan karbohidrat pada lapisan lunak batang pohon pisang pada penelitian ini merupakan penelitian yang baru.

\section{Kesimpulan}

Berdasarkan hasil penelitian maka dapat disimpulkan hasil rata-rata kadar protein dan karbohidrat yang diperoleh pada batang pohon pisang kepok dari daerah Mpanau Kabupaten Sigi yaitu kadar protein pada lapisan keras batang pohon pisang 3,05\%, pada lapisan lunak batang pohon pisang 0,08\%. Kadar karbohidrat pada lapisan keras batang pohon pisang $6,75 \%$ dan pada lapisan lunak batang pohon pisang $4,75 \%$.

\section{Ucapan Terima Kasih}

Ucapan terimakasih kepada laboran laboratorium Kimia FKIP Universitas Tadulako dan semua pihak yang banyak membantu penulis dalam menyelesaikan penelitian ini.

\section{Referensi}

Almatsier, S. (2009). Prinsip dasar ilmu gizi. Jakarta: PT Gramedia Pustaka Utama.

Bintang, M., (2010). Biokimia Teknik Penelitian. Bogor: Erlangga.

Dhalika. T., Budiman. A., Ayuningsih. B., \& Mansyur. (2011). Nilai nutrisi batang pisang dan produk bioproses (ensilage) sebagai ransum lengkap. Jurnal Ilmu Ternak, 11(1), 17-23.

Djaja, W. (2008). Langkah jitu membuat kompos dari kotoran ternak \& sampah. Jakarta: PT. Agro Media Pustaka.

Djoht, D. R. (2002). Etnobotani pisang suku karon: studi tentang ekologi pangan pokok. Antropologi Рapua, 1(2), 33-39.

Ermawati. O. W., Wahyuni. S., \& Rejeki. S. (2016). Kajian pemanfaatan limbah kulit pisang raja (Musa paradisiacal var raja) dalam pembuatan es krim. Jurnal Sains dan Teknologi Pangan, 1(1), 6772.

Faozan, M. (2013). Ekstraksi dan karakterisasi pati biji durian. Skripsi. Palu: Universitas Tadulako. 
Fatemeh, S. R., Saifullah, R., Abbas, F. M. A. \& Azhar, M. E. (2012). Total phenolis, flavonoid and antioxidant activity of banana pulp and peel flours: influence of variety and stage of ripenes. International Food Research Journal. 19(3), 10411046.

Hasrida. (2011). Pengaruh dosis urea dalam amoniasi batang pisang terhadap degradasi bahan kering, bahan organik dan protein kasar secara in-vitro. Padang: Universitas Andalas.

Hidayat, R., Setiawan. A., \& Nofyan. E. (2016). Pemanfaatan limbah kulit pisang lilin (musa paradisiaca) sebagai pakan alternatif ayam pedaging (Gallus galus domesticus). Jurnal Ilmu Lingkungan, 14(1), 11-17.

Munadjim, (1988). Teknologi pengolahan pisang. Jakarta: PT. Gramedia. Diterbitkan dengan kerja sama pemerintah DKI Jakarta.

Nuryani, S. \& Sutanto, R. (2002), Pengaruh sampah kota terhadap hasil dan tanah hara lombok. Jurnal Ilmu Tanah dan Lingkungan, 3(1), 24-28.

Pratama, N. R., Riata, R., Hermawan, A., Ikawati, M., \& Meiyanto, E. (2011). Banana peels (Musa paradisiaca L.) Extract as phytoestrogen on ovariectomized mice mammary gland development by inducing c-myc expression. Indonesian Journal of Cancer Chemoprevention, 2(1), 151-159.

Rahayu, N. A., \& Astuti. N. (2015). Pengaruh jenis pisang dan proporsi pisang dengan air terhadap hasil jadi yoghurt pisang ditinjau dari sifat organoleptik. Jurnal Tata Boga, 4(1), 99-108.
Rahman, H. (2006). Pembuatan pulp dari batang pisang uter (musa paradisiaca linn. var uter) pascapanen dengan proses soda. Skripsi. Yogyakarta: Universitas Gadjah Mada.

Septiani, Y., Purwoko. T., \& Pangastuti. A. (2004). Kadar karbohidrat, lemak dan protein pada kecap dari tempe. Jurnal Bioteknologi, 1(2), 48-53.

Someya, S., Yoshiki, Y \& Okubo, K. (2002). Antioxidant Compounds From Bananas (Musa cavendish). Food Chemistry, 79(3), 351-354.

Sriharti \& Salim, T. (2008). Pemanfaatan limbah pisang untuk pembuatan kompos menggunakan komposter rotary drum. Yogyakarta: LIPI.

Suprihatin. (2011). Proses pembuatan pupuk cair dari batang pohon pisang. Jurnal Teknik Kimia, 5(2), 429-433.

Taufik, R., Rohman, L, \& Riyanti, E. (2011). Optimasi proses pembuatan food bar berbasis pisang. Bandung: Universitas Islam Bandung.

Wina, E. (2001). Tanaman Pisang Sebagai Pakan Ternak Ruminansia. Wartozoa, 11(1), 20-27.

Wulandari, S. A., Mansur. I., \& Sugiarti, H. (2011). Pengaruh pemberian kompos batang pisang terhadap pertumbuhan semai jabon (Anthocephalus cadamba Miq). Jurnal Silvikultur Tropika, 3(1), 78-8. 
